\title{
BIOPROSPEKSI SPONS, KARANG LUNAK DAN ASCIDIAN ASAL TAMAN NASIONAL LAUT KEPULAUAN WAKATOBI: ANTITUMOR DAN ANTIOKSIDAN
}

\section{Bioprospecting of Spons, Soft Coral and Ascidian from Wakatobi Marine Nasional Park : Antitumor and Antioxidant}

\author{
Nurrahmi Dewi Fajarningsih ${ }^{1}$, Muhammad Nursid ${ }^{1}$, Hedi Indra J anuar ${ }^{1}$, dan Thamrin Wikanta ${ }^{1}$ \\ ${ }^{1}$ Balai Besar Penelitian dan Pengembangan Pengolahan Produk dan Bioteknologi Kelautan dan Perikanan, KKP. \\ Jl. K.S. Tubun Petamburan VI, Jakarta Pusat 10260 \\ * Korespondensi Penulis: nurrahmi_dewi@yahoo.com \\ Diterima: 29 Mei 2013, Disetujui: 6 Desember 2013
}

\begin{abstract}
ABSTRAK
Penelitian ini bertujuan untuk mengetahui potensi manfaat (bioprospeksi) spons, karang lunak, dan ascidian asal Taman Nasional Laut (TNL) Kepulauan Wakatobi sebagai antitumor dan antioksidan. Sampel makroinvertebrata laut diambil dengan menggunakan scuba diving di empat stasiun pengambilan di perairan TNL Kep. Wakatobi. Sebanyak 74 sampel diuji aktivitas antitumornya terhadap 3 jenis sel lestari tumor (HeLa, MCF7, SKOV3) dengan metode Thiazolyl Blue Tetrazolium Blue (MTT) dan diuji pula aktivitas antioksidannya dengan menggunakan metode DPPH (2,2-diphenyl pikryl hidrazil). Sampel yang dapat menghambat $>50 \%$ sel lestari tumor pada konsentrasi $20 \mu \mathrm{g} / \mathrm{ml}$ dikategorikan sebagai sampel aktif antitumor. Sampel yang memiliki aktivitas penghambatan radikal bebas $>50 \%$ pada konsentrasi $100 \mu \mathrm{g} / \mathrm{ml}$ dalam uji DPPH dikategorikan sebagai sampel yang aktif antioksidan. Hasil penelitian menunjukkan bahwa terdapat 3 sampel (ascidian W-02-08; spons W-24-08 dan W-25-08) yang aktif terhadap tiga jenis sel lestari tumor, 11 sampel aktif terhadap dua jenis sel lestari tumor dan 22 sampel aktif terhadap satu jenis sel lestari tumor. Dari 74 sampel yang diuji aktivitas antioksidannya, terdapat 8 sampel yang tergolong aktif (7 sampel spons dan 1 sampel karang lunak).
\end{abstract}

KATAKUNCl: $\quad$ spons, karang lunak, ascidian, Wakatobi, antitumor, antioksidan

\section{ABSTRACT}

This research was aimed to investigate the bioprospecting of sponge, soft coral, and ascidian from Wakatobi Marine National Park (MNP) as antitumor and antioxidant. Macroinvertebrate samples were collected from 4 sampling stations of Wakatobi MNP using scuba diving. Seventy four samples were tested its antitumor activity using Thiazolyl Blue Tetrazolium Blue (MTT) assay (against 3 tumor cell lines: HeLa, MCF 7, and SKOV3) and were also tested its antioxidant activity using DPPH (2,2-diphenyl pikryl hidrazil) methode. Samples that inhibit more than $50 \%$ tumor cell line at concentration of $20 \mu \mathrm{g} / \mathrm{ml}$ were considered as antitumor active. While, samples that inhibit more than $50 \%$ free radicals at concentration of $100 \mu \mathrm{g} / \mathrm{ml}$ were considered as antioxidant active. The result showed that 3 sponges samples (ascidian W-02-08; sponge W-24-08 and W-2508) were active againts 3 tumor cell lines, 11 samples were active againts 2 tumor cell lines and 22 samples were active againts 1 tumor cell lines. The antioxidant assay showed that only 8 samples (7 sponge and 1 soft corals) were active as antioxidant.

KEYWORDS: $\quad$ sponge, soft coral, ascidian, Wakatobi, antitumor, antioxidant

\section{PENDAHULUAN}

Indonesia merupakan negara dengan keanekaragaman hayati terbesar kedua di dunia setelah Brasil. Brasil mempunyai daratan yang luas (hutan Amazonia), sedangkan Indonesia mempunyai jumlah pulau yang sangat banyak dengan lautan yang luas. Hal tersebut menjadikan Indonesia sebagai negara dengan keanekaragaman hayati laut (megabiodiversity) tertinggi di dunia.

Keanekaragaman hayati sebanding dengan keanekaragaman kimia bahan alam yang dikandungnya. Kelimpahan dan keanekaragaman kimia bahan alam dengan berbagai bioaktivitas 
potensial kemudian dapat dikembangkan ke tahap penemuan obat. Hingga saat ini, kegiatan bioprospeksi senyawa bahan alam baru dari lingkungan laut telah menghasilkan ribuan senyawa baru (Leal et al., 2012). Hal tersebut menegaskan bahwa organisme laut merupakan sumber penting untuk kegiatan penelitian dan pengembangan obat baru (Williams \& Andersen, 2006).

Spons dan karang lunak merupakan hewan multiseluler dengan tubuh lunak (soft bodied), pertumbuhan yang sangat lambat, sessil dan berwarna terang. Tekanan lingkungan, seperti kompetisi ruang, cahaya, dan sumber lainnya menyebabkan terjadinya keanekaragaman kimia pada berbagai organisme bentik, termasuk spons yang berfungsi sebagai pertahanan diri terhadap serangan predator (Sennet et al., 2002; Leal et al., 2012 ). Spons merupakan makroinvertebrata laut yang menjadi sumber senyawa bioaktif baru dengan berbagai potensi biomedis sebagai antitumor, antimikrobia, antivirus dan lain?lain (Pabel et al., 2003; Mayer et al., 2013).

Beberapa senyawa bioaktif berhasil diisolasi dari spons asal Indonesia, di antaranya senyawa cyclic peptide barangamide $A$ dengan bioaktivitas sebagai senyawa sitotoksik dan inhibitor HIV yang diisolasi dari spons Theonella swinhoei (Faulkner, 2001). Selain itu, Plaza et al. (2009) juga berhasil mengisolasi beberapa senyawa cyclic depsipeptides (celebesides A dan C) baru dari spons Siliquariaspongia mirabilis yang dikoleksi dari perairan Indonesia. Senyawa celebesides $\mathrm{A}$ dan $\mathrm{C}$ tersebut mempunyai aktivitas sebagai anti tumor dan anti?HIV. Senyawa Sintokamide $A$ yang merupakan inhibitor transaktivasi N?terminal dari reseptor androgen pada kanker prostate telah diisolasi oleh Sadar et al (2008) dari spons Dysidea sp. asal Indonesia. Sementara itu, Januar et al. (2010) telah mengisolasi satu senyawa baru dengan formula molekuler $\mathrm{C}_{22} \mathrm{H}_{36} \mathrm{O}_{3}$ dari karang lunak Nepthea sp. yang dikoleksi dari perairan Pulau Seribu, namun senyawa baru tersebut memiliki bioaktivitas antitumor yang lemah terhadap beberapa jenis sel lestari tumor yang diujikan.

Kawasan Wakatobi ditetapkan sebagai Taman Nasional berdasarkan surat keputusan Menteri Kehutanan No. 393/Kpts?VI/1996 dengan luas 1.390.000 hektar. Taman Nasional Laut (TNL) Kepulauan Wakatobi merupakan kawasan konservasi laut dengan potensi sumberdaya alam laut yang bernilai tinggi baik jenis maupun keunikannya sehingga menjadikannya obyek penelitian bioprospeksi yang sangat menarik. Taman Nasional Laut Kep. Wakatobi secara geografis terletak di pusat segitiga karang dunia (coral triangle reef) dan memiliki 25 buah gugusan terumbu karang dengan keliling pantai dari pulau?pulau karang sepanjang $600 \mathrm{~km}$. Sekitar 750 spesies terumbu karang dari total 850 spesies yang terdapat di dunia dapat ditemukan di TNL Kepulauan Wakatobi (Hugua, 2008).

Keanekaragaman hayati laut yang tinggi di TNK Wakatobi dapat memberikan manfaat yang sangat besar. Nursid et al. (2011) melaporkan kapang jenis Emericella nidulans yang diisolasi dari ascidian Aplidium longitorax asal perairan Wakatobi menghasilkan senyawa aktif emestrin yang mempunyai aktivitas sebagai antikanker T47D (payudara) melalui mekanisme apoptosis. Namun demikian, dalam berbagai review ilmiah mengenai present status senyawa bahan alam yang dikoleksi dari invertebrata laut (Mayer et al., 2011; Leal et al., 2012; Mayer et al., 2013), hingga saat ini belum pernah dilaporkan adanya senyawa bahan alam yang diisolasi dari spons, karang lunak ataupun ascidian asal TNL Kep. Wakatobi. Oleh karena itu, kegiatan untuk mencari dan menemukan senyawa bioaktif baru melalui eksplorasi pemanfaatan keanekaragaman hayati (kegiatan bioprospeksi) di TNL Kep. Wakatobi perlu dilakukan untuk mengungkap potensi ?potensi pemanfaatannya. Penelitian ini bertujuan untuk mengetahui potensi manfaat (bioprospeksi) spons, karang lunak dan ascidian asal TNL Kep. Wakatobi sebagai penghasil senyawa bioaktif antitumor dan antioksidan.

\section{BAHANDAN METODE}

Pengambilan Sampel Spons, Karang Lunak dan Ascidian

Pengambilan 74 sampel spons, karang lunak, dan ascidian dilakukan di perairan TNL Kep. Wakatobi pada tanggal 25 dan 26 April 2008. Sampel seberat 50 hingga $550 \mathrm{~g}$ diambil dengan menggunakan scuba diving di 4 stasiun pengambilan di perairan TNK Wakatobi. Keempat stasiun pengambilan tersebut meliputi pesisir Pantai Kapota (S ?5.35 E 123.46), Pesisir Desa Waha (S 5.27 E $\left.123.51^{\circ}\right)$, Tanjung Sombano Kaledupa (S ?5.47 E 123.73) dan Pesisir Pulau Hoga Kaledupa (S ?5.48 E 123.76). Sampel tersebut kemudian langsung dimaserasi dengan menggunakan pelarut etanol dalam tabung tahan pelarut organik, kemudian dibawa ke Laboratorium Instrumen Balai Besar Litbang Pengolahan Produk dan Bioteknologi Kelautan dan Perikanan untuk diekstraksi lebih lanjut. Sebagai dokumentasi, diambil foto spons, karang lunak dan ascidian di habitatnya dan foto di permukaan air. Perkiraan identifikasi sampel dilakukan berdasarkan foto tersebut. 
Ekstraksi Spons, Karang Lunak, dan

Ascidian

Ekstraksi spons, karang lunak, dan ascidian dilakukan menurut Wikanta et al. (2005). Sampel dimaserasi dengan pelarut etanol teknis $95 \%$ selama 72 jam kemudian maserat disaring. Maserat kemudian dievaporasi pada suhu $25^{\circ} \mathrm{C}$ dan tekanan $40 \mathrm{Mbar}$ menggunakan Buchi R otavapor. Setelah pelarut etanol menguap semua, ekstrak dikeringbekukan pada suhu dan tekanan rendah ( $? 40^{\circ} \mathrm{C}, 300 \times 10^{? 3} \mathrm{Mbar}$ ) dengan menggunakan freeze dryer (Labconco) hingga diperoleh ekstrak berbentuk serbuk kering.

Uji Sitotoksisitas Terhadap Sel Kanker

HeLa, MCF 7, dan SKOV 3

Uji sitotoksisitas dilakukan dengan metode MTT (3?[4,5?dimetilthiazol?2yl]?2,5?difenil tetrazolium bromida) menurut Zachary (2003). Sel HeLa dan SKOV 3 dikultur dalam media RPMI (R oswell Park Memorial Institue) 1640, sementara sel MCF 7 dikultur pada media DMEM (Dulbeccoß Modified Eagleß Medium). Medium RPMI dan DMEM dilengkapi dengan Fetal Bovine Serum (FBS) 10\%, fungizone $0,5 \%$ dan Penisilin?Streptomisin 2\%.

Sebanyak $100 \mu$ larutan ekstrak spons, karang lunak, dan ascidia dimasukkan ke dalam sumuran mikroplat yang telah berisi sel tumor sebanyak $2 \times 10^{4}$ sel $(100 \mu \mathrm{l})$, kemudian diinkubasi selama 24 jam dalam inkubator $\mathrm{CO}_{2}$. Selanjutnya, masing?masing ekstrak spons, karang lunak dan ascidian diuji pada konsentrasi 20 ?g/ml sebanyak 3 ulangan. Dibuat pula 3 macam kontrol, yaitu: kontrol sel $(100 \mu \mathrm{l} \mathrm{sel}+100$ $\mu \mathrm{l}$ media), kontrol media ( $200 \mu \mathrm{l}$ media) dan kontrol sampel $(100 \mu \mathrm{l}$ ekstrak spons $+100 \mu \mathrm{l}$ media). Kemudian mikroplat diinkubasikan selama 24 jam dalam inkubator $\mathrm{CO}_{2}$. Efek ekstrak terhadap perubahan morfologi sel lestari tumor yang diujikan kemudian diamati dan difoto sebagai dokumentasi. Setelah diinkubasikan selama 24 jam, selanjutnya ke dalam mikroplat ditambahkan $10 \mu \mathrm{l}$ MTT ke dalam tiap sumuran dan diinkubasikan kembali selama 4 jam dalam inkubator $\mathrm{CO}_{2}$. Reaksi MTT dihentikan dengan penambahan sodium dodesil sulfat (SDS) $10 \%$, selanjutnya mikroplat kembali diinkubasikan selama 12 jam dalam ruang gelap pada suhu kamar. Setelah inkubasi tersebut, absorbansi tiap sumuran diukur dengan microplate reader (DY NEX spektrofotometer) pada panjang gelombang $570 \mathrm{~nm}$.

Penentuan persentase kematian sel dihitung berdasarkan rumus:

$\%$ Mortalitas $=\frac{(A-D)(B-C)}{(A-D)} \times 100 \%$

Keterangan: $\quad A=$ Absorbansi kontrol sel

$$
\begin{aligned}
& B=\text { Absorbansi sampel } \\
& C=\text { Absorbansi kontrol sampel } \\
& D=\text { Absorbansi kontrol media }
\end{aligned}
$$

\section{Uji Antioksidan dengan Metode DPPH}

Uji antioksidan dilakukan dengan metode DPPH menurut Yong Li et al. (2006). Ekstrak spons, karang lunak, dan ascidian asal TNL Kep. Wakatobi diuji pada konsentrasi $100 \mu \mathrm{g} / \mathrm{ml}$ dalam larutan metanol p.a. Sebanyak $160 \mu$ l ekstrak dimasukkan ke dalam sumuran mikroplat kemudian ke dalam masing? masing sumuran ditambahkan 40 ?I larutan DPPH (Merck). Larutan DPPH dibuat dengan cara melarutkan $3 \mathrm{mg}$ DPPH dalam $10 \mathrm{ml}$ metanol p.a. Sebagai kontrol sampel, sebanyak 160 ? l ekstrak dari masing?masing sampel dimasukkan ke dalam sumuran lalu ditambahkan $40 \mu \mathrm{l}$ metanol p.a. Kontrol negatif dibuat dengan cara menambahkan $160 \mu$ l metanol p.a dengan $40 \mu \mathrm{IDPPH}$ dan sebagai blanko digunakan $200 \mu \mathrm{l}$ metanol p.a. Asam askorbat (Merck) konsentrasi $100 \mu \mathrm{g} / \mathrm{ml}$ digunakan sebagai kontrol positif. Mikroplat diinkubasi pada suhu ruang selama 30 menit, kemudian absorbansi dari tiap sumuran dibaca dengan microplate reader (Dynex) pada panjang gelombang $510 \mathrm{~nm}$. Persentase penghambatan radikal bebas ditentukan dengan rumus:

$$
\begin{aligned}
\% \text { hambatan }= & \frac{(A-B)-(C-D)}{(A-B)} \times 100 \% \\
\text { Keterangan: } \quad & A=\text { absorbansi kontrol negatif } \\
& B=\text { absorbansi blanko } \\
& C=\text { absorbansi sampel } \\
D & =\text { absorbansi kontrol sampel }
\end{aligned}
$$

\section{HASIL DAN BAHASAN}

\section{Aktivitas Antitumor Esktrak Spons, Karang Lunak, dan Ascidia}

Menurut kriteria National Cancer Institute ( $\mathrm{NCl}$ ) suatu ekstrak dikategorikan aktif apabila $\mathrm{IC}_{50}$ nya < $20 \mu \mathrm{g} / \mathrm{ml}$ (Schmitz et al., 2001). Ekstrak yang dikategorikan aktiflah yang kemudian diteliti lebih lanjut untuk diisolasi senyawa aktifnya. Berdasarkan kriteria tersebut, pada penelitian ini, masing?masing ekstrak spons, karang lunak, dan ascidian diuji aktivitas sitotoksiknya pada konsentrasi $20 \mu \mathrm{g} / \mathrm{ml}$ terhadap 3 jenis sel lestari tumor. Apabila pada konsentrasi $20 \mu \mathrm{g} / \mathrm{ml}$, ekstrak tersebut dapat menghambat $50 \%$ atau lebih sel lestari tumor maka dikategorikan sebagai sampel aktif. Ketiga jenis sel yang diujikan adalah sel HeLa (sel tumor serviks), sel MCF7 (sel tumor payudara) dan sel SKOV3 (sel tumor ovarium). Persentase kematian ketiga jenis sel setelah 
Tabel 1. Persen kematian sel tumor HeLa, MCF 7, dan SKOV 3 yang diperlakukan dengan ekstrak spons, karang lunak, dan ascidian yang diuji pada konsentrasi uji 20 ?g/ml

Table 1. Percent mortality of HeLa, MCF 7, and SKOV 3 cell lines treated with sponge, soft coral, and ascidian extracts at concentration of $20 \mathrm{~g} / \mathrm{ml}$

\begin{tabular}{|c|c|c|c|c|c|}
\hline \multirow{2}{*}{ No } & \multirow{2}{*}{ Kode/Code } & \multirow{2}{*}{ Kelompok/Group } & \multicolumn{3}{|c|}{ \% Kematian / \% Mortality } \\
\hline & & & HeLa & MCF 7 & SKOV 3 \\
\hline 1 & W?01?08 & Karang Lunak/S oft C oral & 47.00 & 53.50 & 53.30 \\
\hline 2 & W?02?08 & As cidian & 55.20 & 70.80 & 65.40 \\
\hline 3 & W?03?08 & Karang Lunak/S oft C oral & 38.90 & 21.90 & 40.90 \\
\hline 4 & W?04?08 & Spons/Sponge & 37.34 & 45.49 & 97.02 \\
\hline 5 & W?05?08 & Karang Lunak/S oft C oral & 34.79 & 0 & 27.31 \\
\hline 6 & W?06?08 & Spons/Sponge & 21.40 & 17.20 & 35.70 \\
\hline 7 & W?07?08 & Spons/Sponge & 25.30 & 51.10 & 45.50 \\
\hline 8 & W?08?08 & Spons/Sponge & 19.10 & 27.10 & 74.60 \\
\hline 9 & W?09?08 & Spons/Sponge & 41.90 & 25.00 & 66.30 \\
\hline 10 & W?10?08 & Spons/Sponge & 57.70 & 47.28 & 40.35 \\
\hline 11 & W?11?08 & Spons/Sponge & 7.08 & 56.26 & 0 \\
\hline 12 & W?12?08 & Spons/Sponge & 27.4 & 67.4 & 23.64 \\
\hline 13 & W?13?08 & Karang Lunak/S oft C oral & 48.14 & 38.4 & 44.95 \\
\hline 14 & W?14?08 & Spons/Sponge & 49.10 & 65.60 & 47.40 \\
\hline 15 & W?15?08 & Spons/Sponge & 95.08 & 47.28 & 40.35 \\
\hline 16 & W?16?08 & Spons/Sponge & 95.57 & 100.00 & 29.87 \\
\hline 17 & W?17?09 & Spons/Sponge & 12.97 & 0 & 0 \\
\hline 18 & W?18?08 & Spons/Sponge & 23.67 & 5.62 & 11.52 \\
\hline 19 & W?19?08 & Spons/Sponge & 63.81 & 49.01 & 43.60 \\
\hline 20 & W?20?08 & Spons/Sponge & 35.44 & 28.91 & 21.54 \\
\hline 21 & W?21?08 & Spons/Sponge & 62.83 & 12.61 & 29.26 \\
\hline 22 & W?22?08 & Karang Lunak/S oft Coral & 0 & 0 & 58.20 \\
\hline 23 & W?23?08 & Karang Lunak/S oft C oral & 43.22 & 0 & 43.02 \\
\hline 24 & W?24?08 & Spons/Sponge & 67.70 & 66.60 & 85.60 \\
\hline 25 & W?25?08 & Spons/Sponge & 79.90 & 97.30 & 83.00 \\
\hline 26 & W?26?08 & Spons/Sponge & 33.50 & 36.74 & 24.48 \\
\hline 27 & W?27?08 & Karang Lunak/S oft C oral & 32.20 & 61.10 & 41.50 \\
\hline 28 & W?28?08 & Karang Lunak/S oft C oral & 28.63 & 8.15 & 43.97 \\
\hline 29 & W?29?08 & Spons/Sponge & 40.70 & 15.54 & 56.23 \\
\hline 30 & W?30?08 & Spons/Sponge & 44.41 & 12.5 & 28.44 \\
\hline 31 & W?31?08 & Karang Lunak/S oft C oral & 57.70 & 60.9 & 29.40 \\
\hline 32 & W?32?08 & Karang Lunak/S oft C oral & 22.94 & 10.53 & 37.36 \\
\hline 33 & W?33?08 & Spons/Sponge & 18.22 & 0 & 40.30 \\
\hline 34 & W?34?08 & Spons/Sponge & 32.14 & 37.39 & 100.00 \\
\hline 35 & W?35?08 & Spons/Sponge & 67.86 & 0 & 38.44 \\
\hline 36 & W?36?08 & Spons/Sponge & 34.49 & 40.79 & 44.13 \\
\hline 37 & W?37?08 & Spons/Sponge & 26.69 & 6.47 & 0.84 \\
\hline 38 & W?38?08 & Spons/Sponge & 0 & 58.45 & 64.74 \\
\hline 39 & W?39?08 & Spons/Sponge & 17.63 & 0 & 37.88 \\
\hline 40 & W?40?08 & Spons/Sponge & 46.88 & 37.74 & 18.67 \\
\hline 41 & W?41?08 & Karang Lunak/S oft C oral & 9.16 & 0 & 27.08 \\
\hline
\end{tabular}


Tabel 1. Persen kematian sel tumor HeLa, MCF 7, dan SKOV 3 yang diperlakukan dengan ekstrak spons, karang lunak, dan ascidian yang diuji pada konsentrasi uji $20 \mu \mathrm{g} / \mathrm{ml}$ (lanjutan)

Table 1. Percent mortality of HeLa, MCF 7, and SKOV 3 cell lines treated with sponge, soft coral, and ascidian extracts at concentration of $20 \mu \mathrm{g} / \mathrm{ml}$ (continued)

\begin{tabular}{|c|c|c|c|c|c|}
\hline \multirow{2}{*}{ No } & \multirow{2}{*}{ Kode/Code } & \multirow{2}{*}{ Kelompok/Group } & \multicolumn{3}{|c|}{ \%Kematian / \% Mortality } \\
\hline & & & HeLa & MCF 7 & SKOV 3 \\
\hline 42 & W?42?08 & Spons/Sponge & 50.40 & 71.50 & 44.80 \\
\hline 43 & W?43?08 & Spons/Sponge & 5.67 & 0 & 57.26 \\
\hline 44 & W?44?08 & Spons/Sponge & 75.40 & 33.10 & 54.20 \\
\hline 45 & W?45?08 & Karang Lunak/S oft Coral & 50.40 & 33.90 & 40.50 \\
\hline 46 & W?46?08 & Spons/Sponge & 1.12 & 90.15 & 0 \\
\hline 47 & W?47?08 & Karang Lunak/S oft Coral & 34.10 & 68.10 & 37.40 \\
\hline 48 & W?48?08 & Karang Lunak/S oft Coral & 32.70 & 22.40 & 0 \\
\hline 49 & W?49?08 & Spons/Sponge & 3.55 & 0 & 38.72 \\
\hline 50 & W?50?08 & Spons/Sponge & 26.10 & 86.90 & 90.90 \\
\hline 51 & W?51?08 & Karang Lunak/S oft Coral & 24.00 & 64.10 & 74.20 \\
\hline 52 & W?52?08 & Karang Lunak/S oft Coral & 32.67 & 19.07 & 56.54 \\
\hline 53 & W?53?08 & Spons/Sponge & 23.14 & 8.85 & 7.36 \\
\hline 54 & W?54?08 & $\begin{array}{c}\text { Spons yang Tidak Teridentifikasi/ } \\
\text { unidentified sponge }\end{array}$ & 25.47 & 0 & 17.60 \\
\hline 55 & W?55?08 & Spons/Sponge & 32.23 & 16.9 & 28.12 \\
\hline 56 & W?56?08 & Spons/Sponge & 54.70 & 45.10 & 65.20 \\
\hline 57 & W?57?08 & Spons/Sponge & 20.90 & 5.62 & 31.21 \\
\hline 58 & W?58?08 & Karang Lunak/S oft Coral & 21.34 & 13.94 & 9.53 \\
\hline 59 & W?59?08 & Karang Lunak/S oft Coral & 33.20 & 28.00 & 67.10 \\
\hline 60 & W?60?08 & Karang Lunak/S oft Coral & 63.40 & 0 & 50.20 \\
\hline 61 & W?61?08 & Spons/Sponge & 28.16 & 45.71 & 44.93 \\
\hline 62 & W?62?08 & Spons/Sponge & 29.90 & 9.70 & 43.70 \\
\hline 63 & W?63?08 & Spons/Sponge & 10.60 & 2.30 & 42.90 \\
\hline 64 & W?64?08 & Spons/Sponge & 42.55 & 26.22 & 50.35 \\
\hline 65 & W?65?08 & Spons/Sponge & 43.40 & 51.70 & 51.90 \\
\hline 66 & W?66?08 & Spons/Sponge & 9.75 & 20.19 & 30.76 \\
\hline 67 & W?67?08 & Spons/Sponge & 42.55 & 22.04 & 31.76 \\
\hline 68 & W?68?08 & Karang Lunak/S oft Coral & 26.82 & 0 & 48.58 \\
\hline 69 & W?69?08 & Spons/Sponge & 15.60 & 29.50 & 50.20 \\
\hline 70 & W?70?08 & Spons/Sponge & 30.97 & 27.69 & 60.39 \\
\hline 71 & W?71?08 & Spons/Sponge & 13.55 & 0 & 29.61 \\
\hline 72 & W?72?08 & Spons/Sponge & 19.05 & 0 & 0.83 \\
\hline 73 & W?73?08 & Spons/Sponge & 60.98 & 26.88 & 58.63 \\
\hline 74 & W?74?08 & Spons/Sponge & 43.40 & 19.90 & 33.30 \\
\hline
\end{tabular}

diperlakukan dengan ekstrak spons, karang lunak, dan ascidian (Tabel 1).

Ada dua model yang dikembangkan dalam riset pencarian senyawa bioaktif antitumor dari bahan alam. Model pertama adalah mencari bahan alam yang memiliki toksisitas yang tinggi (sangat toksik terhadap berbagai jenis sel). Sedangkan model yang lain adalah mencari senyawa bioaktif yang dapat membunuh sel tumor secara spesifik (Boyd, 1997). Hasil penelitian ini menunjukkan bahwa terdapat 3 sampel (W?02?08; W?24?08; W?25?08) yang aktif terhadapga jenis sel lestari tumor yang diujikan. Terdapat 11 sampel aktif terhadap dua jenis sel lestari tumor (3 sampel aktif terhadap HeLa dan MCF7; 2 sampel aktif terhadap sel HeLa dan SKOV3; 4 sampel aktif terhadap sel MCF7 dan SKOV3). Selain itu, terdapat 22 sampel aktifitasnya bersifat selektif terhadap satu jenis sel lestari tumor ( 6 sampel aktif terhadap HeLa; 6 sampel aktif terhadap sel MCF7 dan 10 sampel aktif terhadap sel SKOV3) dan 38 sampel yang lain tidak aktif terhadap sel lestari tumor yang diujikan.

Tiga jenis ekstrak yang mampu mematikan 3 jenis sel diatas 50\% adalah ekstrak W?02?08, W?24?08, 
dan W?25?08 (Gambar 1). Morfologi sel Hela, MCF7, dan SKOV3 setelah diberi perlakuan ke?3. Jenis ekstrak tersebut disajikan pada Gambar 2,3, dan 4. Ekstrak yang aktif dapat merubah morfologi sel. Dalam hal ini sel kehilangan integritasnya dan dibawah mikroskop, sel terlihat hancur dengan bentuk yang tidak beraturan. Dalam kondisi seperti ini sel sudah terlepas dari dasar flask culture yang digunakan sebagai substratnya. Banyak ahli yang menduga (Pawlik, 1993; Schmitz, 2001; Williams \& Andersen, 2006) bahwa metabolit sekunder pada spons dan karang lunak berhubungan erat dengan fungsinya

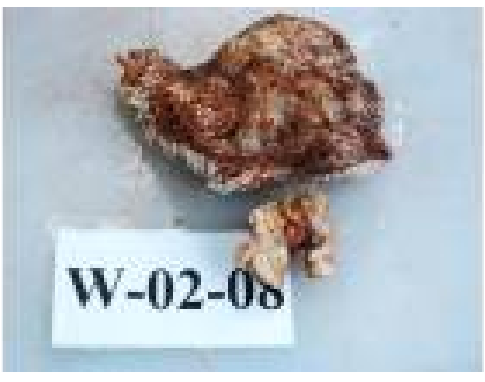

(A)

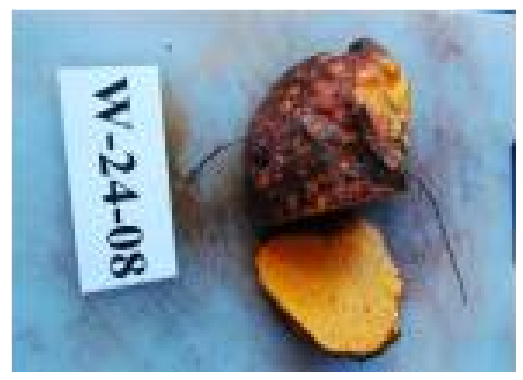

(B)

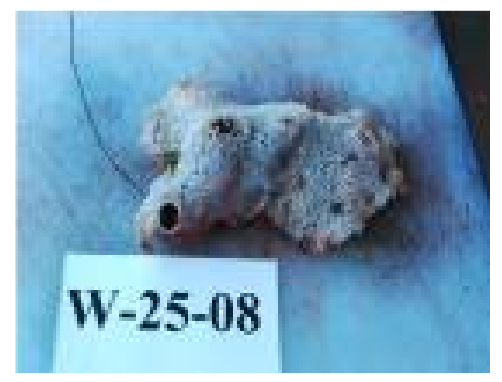

(C)

Gambar 1. Ketiga jenis sampel yang ekstraknya aktif terhadap 3 jenis sel lestari tumor (A)Ascidian W-02-08 (tidak teridentifikasi), (B) Spons W-24-08 (Aaptos sp.) dan (C) Spons W-25-08 (Tak Teridentifikasi).

Picture 1. Three specimens that the crude extracts were active against 3 tumor cell lines (A) Ascidian W02-08 (unidentified), (B) Sponge W-24-08 (Aaptos sp.) and (C) Sponge W-25-08 (not identified).

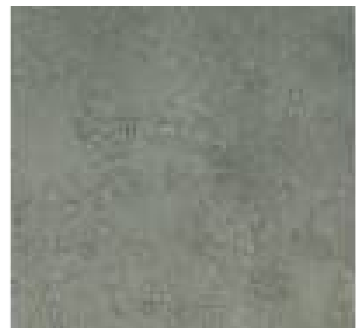

(a)

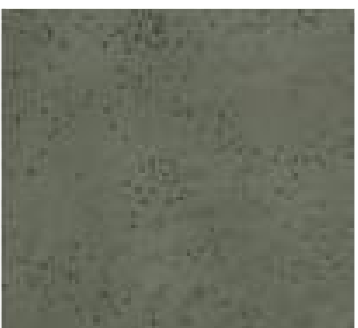

(b)

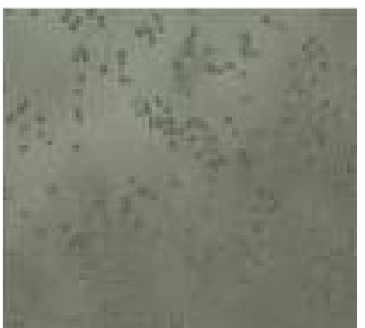

(c)

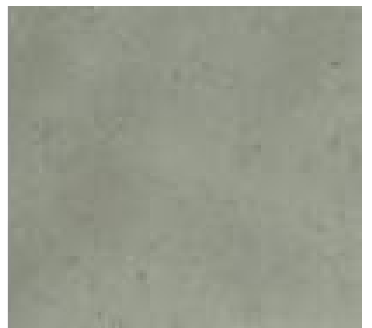

(d)

Gambar 2. Foto morfologi sel HeLa setelah diberi perlakuan ekstrak selama 24 jam (a) kontrol sel; (b) W-0208; (c) W-24-08; (d) W-25-08.

Figure 2. Picture of HeLa cell lines morphology after 24 hours treated with extract of (a) cell control; (b) W02-08; (c) W-24-08; (d) W-25-08.

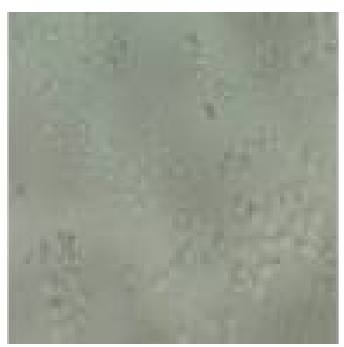

(a)

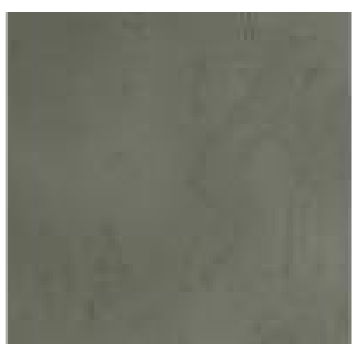

(b)

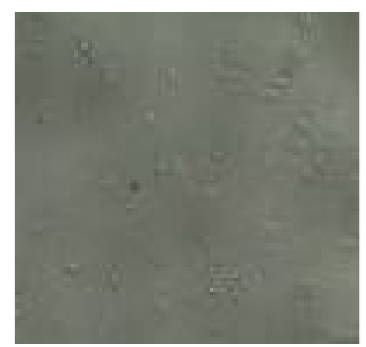

(c)

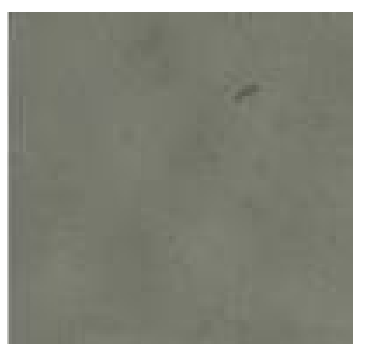

(d)

Gambar 3. Foto morfologi sel MCF7 setelah diberi perlakuan ekstrak selama 24 jam (a) kontrol sel; (b) W02-08; (c) W-24-08; (d) W-25-08.

Figure 3. Picture of MCF7 cell lines morphology after 24 hours treated with extract of (a) cell control; (b) W02-08; (c) W-24-08; (d) W-25-08. 


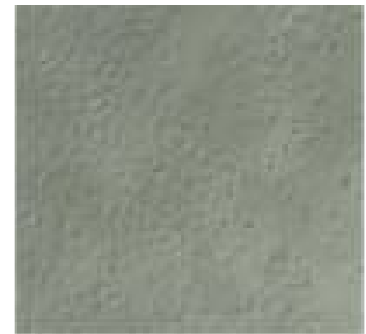

(a)

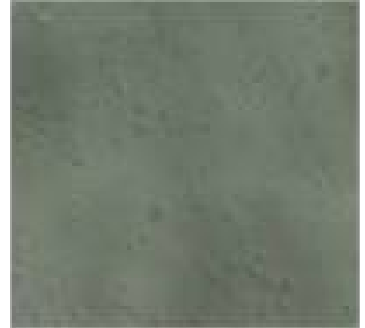

(b)

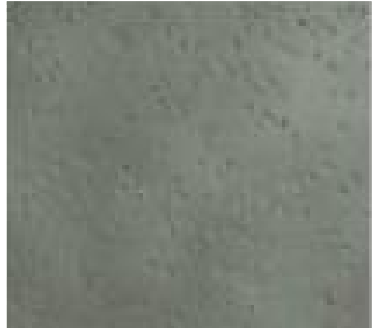

(c)

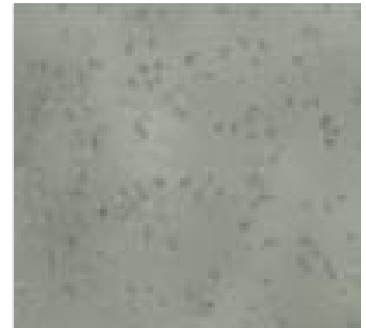

(d)

Gambar 4. Foto morfologi sel SKOV 3 setelah diberi perlakuan ekstrak selama 24 jam (a) kontrol sel; (b) W02-08; (c) W-24-08; (d) W-25-08.

Figure 4. Picture of SKOV 3 cell lines morphology after 24 hours treated with extract of (a) cell control; (b) W-02-08; (c) W-24-08; (d) W-25-08.

sebagai pertahanan diri terhadap serangan predator. Dari 54 sampel ekstrak spons dan ascidia yang diteliti aktivitas sitotoksiknya terdapat 2 sampel spons (W? 24?08 dan W?25?08) dan 1 sampel ascidia (W?02?08) \& yang aktif terhadap 3 jenis sel lestari tumor yang diujikan dan 7 sampel spons aktif terhadap 2 jenis sel tumor (W?16?08, W?38?08,W?42?08,W?44?08,W 50?08,W?56?08,W?73?08). Sementara itu, dari 20 mempunyai aktivitas sebagai antitumor yang baik sampel ekstrak karang lunak yang diteliti, terdapat 4 sampel (W?01?08; W?31?08; W?51?08; dan W?60?08; yang menunjukkan aktivitas sitotoksik terhadap 2 jenis sel lestari tumor yang diujikan namun tidak ada sampel yang aktif terhadap 3 jenis sel tumor yang diujikan. Dibandingkan dengan tubuh spons yang lunak dan berpori, karang lunak mempunyai tubuh yang lebih keras dibandingkan spons, bahkan beberapa jenis spesies karang lunak memiliki semacam duri yang diduga berfungsi sebagai pertahanan fisik terhadap predator. Dibandingkan karang lunak, spons merupakan organisme yang tidak memiliki pertahanan fisik dan bersifat sessil sehingga hanya mengandalkan senyawa kimia sebagai pertahanan diri terhadap predator (Nursid et al., 2006; Larghi et al., 2009). Karena hal itulah, senyawa bioaktif baru lebih banyak diisolasi dari spons dibandingkan dari karang lunak. Dilaporkan oleh Lael et al (2012), diantara 4 kelas anggota filum porifera, kelas demospongia (sponge) merupakan penyumbang senyawa bahan alam baru terbesar dengan persentase mencapai $99,8 \%$. Trianto et al. (2004) melakukan skrining bahan antikanker L1210 pada berbagai jenis spons dan gorgonian yang dikoleksi dari Perairan Jepara dan Flores dan mendapatkan beberapa sampel spons yang mampu menghasilkan senyawa aktif anti kanker L1210, di antaranya ekstrak spons Xestospongia sp., Phyllospongia sp., dan Agelas nakamurai.

Spons dan ascidian menghasilkan senyawa? senyawa yang mengandung nitrogen, yang dikenal sebagai senyawa alkaloid. Senyawa alkaloid mempunyai efek sitologis (siklus sel) sehingga dilaporkan memiliki banyak bioaktivitas, di antaranya sebagai antibakteri, antikoagulan, antiviral, antifungal, antituberculosis, antimalaria dan antitumor (Erpenbeck ) \& van Soest, 2007; Larghi et al, 2009). Genus Aaptos dikenal sebagai produsen senyawa alkaloid $1 \mathrm{H}$ ? benzo[de][1,6]?naphtyridine alkaloids atau aaptamin. terhadap sel HeLa (Nakamura 1982 dalam Larghi et 8)I., 2009), sel MCF?7 dan sel KB (Calculet al., 2003), sel P388, KB16, A549 dan HT?29 (Shenet al, 1999). Spons MFW?24?08, yang merupakan ekstrak teraktif pada bioprospeksi ekstrak spons dan karang lunak asal perairan TNL Wakatobi ini diidentifikasi sebagai Aaptos sp. Diduga kuat, senyawa yang bertanggungjawab terhadap aktivitas antitumor esktrak MFW?24?08 merupakan senyawa aaptamin atau derivatnya.

Dalam review yang ditulis oleh Leal et al (2012), sejak tahun 1990?2009 terdapat 9812 senyawa bahan alam baru yang berhasil diisolasi dari biota laut. Pada dekade 1990 an sebanyak 450,8?70,9 senyawa baru berhasil diisolasi dari biota laut pertahunnya. Angka tersebut kemudian meningkat pada dekade 2000an, yaitu rata?rata 530,4?63,2 senyawa bahan alam baru berhasil diisolasi dari biota laut pertahunnya. Dalam review Farmakologi Laut tahun 2007?8 (Mayeret al., 2011) dan tahun 2009?2011 (Mayer et al., 2013) dilaporkan bahwa sebagian besar senyawa bahan alam laut baru dari laut memiliki bioaktivitas sebagai antibakteri, antivirus, antitumor, antituberculosis, antioksidan, antidiabetes dan antiinflamasi.

\section{Aktivitas Antioksidan}

Oksidasi yang disebabkan oleh senyawa radikal bebas dapat menyebabkan peroksidasi lipid, kerusakan membran protein dan mutasi DNA. Hal tersebut merupakan pemicu terjadinya berbagai penyakit seperti kanker, penyakit kardiovaskuler dan 


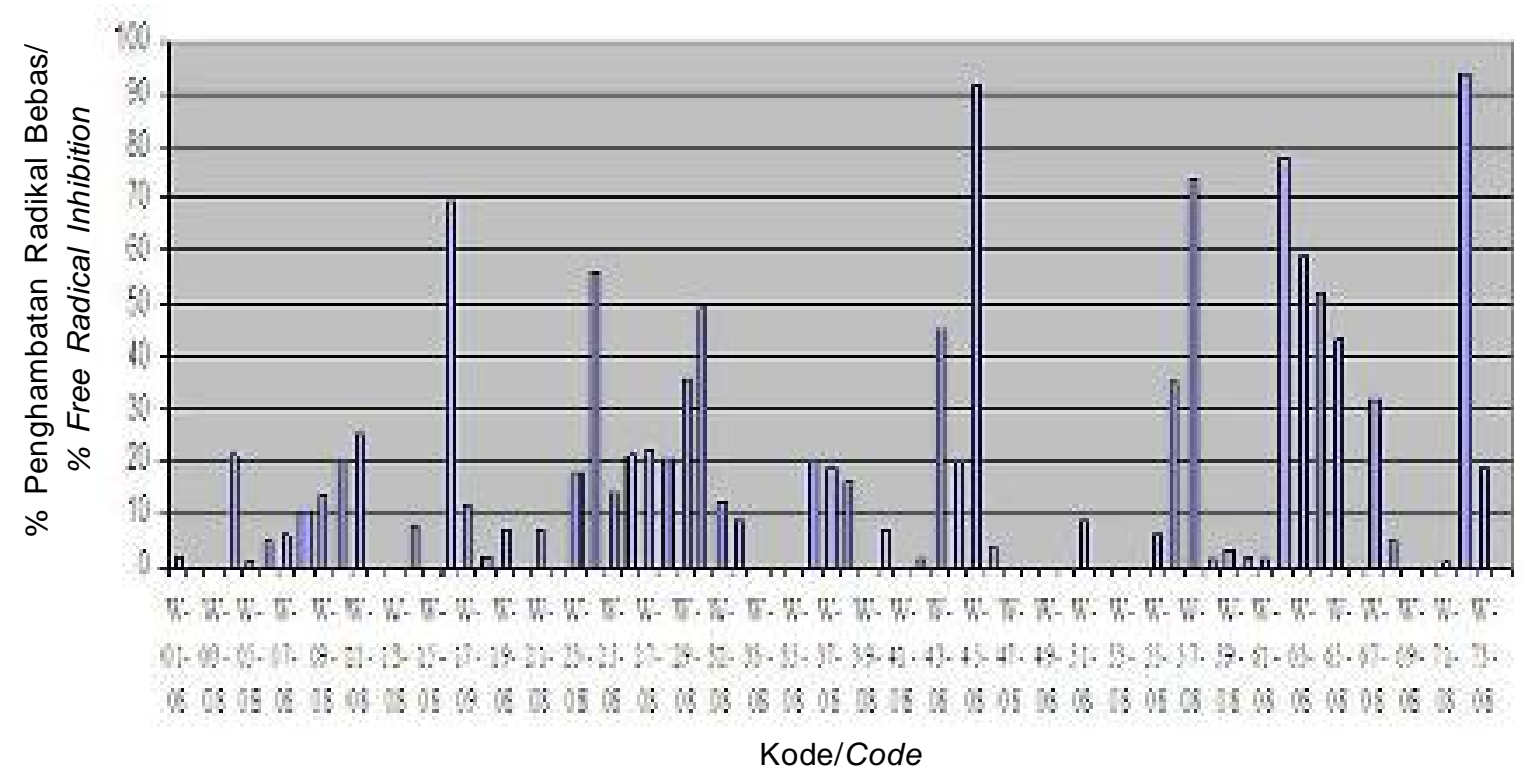

Gambar 5. Persentase penghambatan radikal bebas DPPH ekstrak spons dan karang lunak asal TNK Wakatobi yang diuji pada konsentrasi $100 \mu \mathrm{g} / \mathrm{ml}$.

Picture 5. DPPH free radical scavenging percentage of Wakatobi Marine Nasional Park sponges and soft corals extract at concentration of $100 \mu \mathrm{g} / \mathrm{ml}$.

atherosclerosis. Senyawa antioksidan dengan aktivitas antiradikalnya memegang peranan penting dalam pencegahan perkembangan berbagai penyakit tersebut. Sampai saat ini penelitian untuk mengungkap potensi antioksidan spons dan karang lunak masih sangat sedikit. Padahal banyak senyawa baru yang ditemukan dari spons dan karang lunak merupakan senyawa-senyawa benzenoid (phenol) yang merupakan senyawa aktif antioksidan (Utkina et al., 2004). Menurut Blois (1958), suatu bahan dikategorikan memiliki aktivitas antioksidan yang kuat jika $\mathrm{IC}_{50}$ nya di bawah $200 \mathrm{mg} / \mathrm{L}$. Pada penelitian ini, kami kategorikan suatu sampel memiliki aktifitas antioksidan yang kuat apabila mampu meredam radikal bebas DPPH > 50\% pada konsentrasi uji 100 $\mathrm{g} / \mathrm{ml}$. Hasil uji antioksidan ekstrak spons dan karang lunak asal TNK Wakatobi dengan menggunakan metode DPPH disajikan pada Gambar 5.

Dapat kita ketahui dari Gambar 5, hanya terdapat 8 sampel dari 74 sampel yang diujikan yang memperlihatkan aktivitas peredaman radikal bebas DPPH (antioksidan). Namun demikian, terdapat 2 sampel yang menunjukkan aktivitas peredaman radikal bebas DPPH yang sangat baik. Sampel karang lunak W?45?08 dapat meredam $91,7 \%$ radikal bebas DPPH, bahkan spons W?72?08 dapat meredam 94,1\% radikal bebas dalam uji DPPH yang berarti melebihi aktivitas peredaman radikal bebas asam askorbat (kontrol positif) yang sebesar 92,1 ?g/ml. Sementara itu, Hanani et al. (2005) mengidentifikasi senyawa antioksidan dalam spons Callyspongia sp dari Kepulauan Seribu
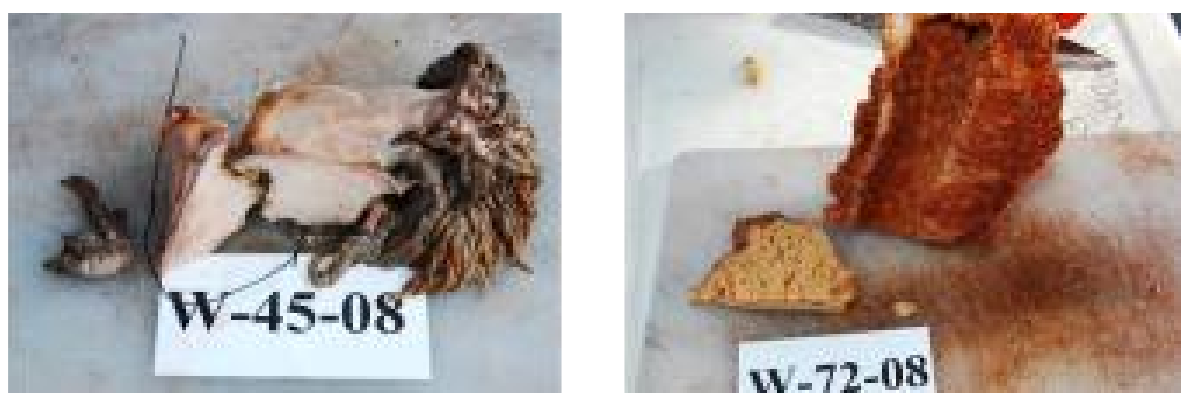

Gambar 6. (A) Karang lunak W-45-08 dan (B) spons W-72-08 dengan aktivitas antioksidan terbaik .

Picture 6. (A) Soft coral specimen W-45-08 and (B) sponge specimen W-72-08 with the highest antioxidant activity. 
sebagai golongan alkaloid dengan IC? $?_{50}$ sebesar 41,21 $? \mathrm{~g} / \mathrm{ml}$.

Menurut Athukorala et al. (2006), senyawa? senyawa aktif antioksidan kemungkinan besar mengandung senyawa polifenol yang tinggi. Beberapa senyawa metabolit sekunder yang diisolasi dari spons dilaporkan memiliki aktivitas antioksidan. Senyawa? senyawa tersebut diantaranya senyawa turunan indol, alkaloid aromatik, poliketida aromatik dan senyawa yang mengandung fenol (Perdicaris et al., 2013).

\section{KESIMPULAN}

Hasil penelitian menunjukkan beberapa jenis spons, karang lunak dan ascidian asal Taman Nasional Laut Kepulauan Wakatobi mempunyai bioprospeksi sebagai penghasil senyawa bioaktif antitumor dan antioksidan. Terdapat 3 sampel ( ascidian W?02?08; spons W?24?08 \& W?25?08) yang aktif terhadap tiga jenis sel lestari tumor, 11 sampel aktif terhadap dua jenis sel lestari tumor dan 22 sampel aktif terhadap satu jenis sel lestari tumor. Dari 74 sampel yang diuji aktivitas antioksidannya, terdapat 8 sampel yang tergolong aktif ( 7 sampel spons dan 1 sampel karang lunak). Sampel spons W?72?08 mempunyai aktivitas antioksidan yang lebih tinggi dibandingkan asam askorbat (kontrol positif).

\section{UCAPAN TERIMA KASIH}

Ucapan terima kasih disampaikan kepada Pak Rachmat dan rekan?rekan dari Balai Taman Nasional Laut Kepulauan Wakatobi atas bantuannya dalam kegiatan pengambilan sampel spons dan karang lunak di TNK Wakatobi.

\section{DAFTAR PUSTAKA}

Athukorala,Y., Kim, K. N. and Jeon, Y. J. 2006. Antiproliferative and antioxidant properties of an enzymatic hydrolysate from brown alga, Ecklonia cava. Food and Chemical Toxicology. 44: 1065?1074.

Blois, M. S. 1958. Antioxidant determinations by the use of a stable free radical. Nature. 181: 1199?1200. Doi: 10.1038/1811199a0

Boyd, M. R. 1997. The $\mathrm{NCl}$ in vitro anticancer drug discovery screen. Concept, implementation and operation, 1985?1995 In: Teicher, B.A (ed.). Anticancer drug development guide: preclinical screening, clinical trials, and approval. Humana Press.

Calcul, L. A., Longeon, A., Al?Mourabit, A., Guyot, M., Bourguet?Kondracki, L. 2003. Novel alkaloids of the aaptamine class from an Indonesian marine sponge of the genus Xestospongia. Tetrahedron. 59: 6539? 6544
Erpenbeck, D., and van Soest, R. W. M. 2007. Status and perspective of sponge chemosystematics. Marine Biotechnology. 9(1): 2?19.

Faulkner, D. J. 2001. Marine Natural Products. Nat. Prod. Rep. 18: 1?49.

Hanani, E., Mun?im, A., dan Sekarini, R. 2005. Identifikasi senyawa antioksidan dalam spons Callyspongia sp. dari Kepulauan Seribu. Majalah IImu Kefarmasian. II (3): $127 ? 133$.

Hugua. 2008. Welcome to Wakatobi regency. http:// www.wakatobi.info. Diakses pada tanggal 11 Juli 2008.

Januar, H. I., Chasanah, E., Motti, C. A., Tapiolas, D. M., Liptrot, C. H., and Wright, A. D. 2010. Cytotoxic cembranes from Indonesian specimens of the soft coral Nephthea sp. Mar. Drugs. 8: 2142 ?2152. Doi:10.3390/md8072142

Larghi, E. L., Bohn, M. L., and Kaufman, T.S. 2009. Aaptamine and related products. Their isolation, chemical syntheses, and biological activity. Tetrahedron. 65: 4257?4282

Leal, M. C., Puga, J., Serodio, J., Gomes, N. C. M., Calado, R. 2012. Trends in the discovery of new marine natural products from invertebrates over the last two decades?Where and what are we bioprospecting? Plos One. 1 (1): 1 ?16.

Mayer, A. M. S., Rodriguez, A. D., Taglialatela?Scafati, O., and Fusetani, N. 2013. Marine pharmacology in 2009?2011: marine compounds with antibacterial, antidiabetic, antifungal, anti?inflammatory, antiprotozoal, antituberculosis, and antiviral activities; affecting the immune and nervous systems, and other miscellaneous mechanisms of action. Mar. Drugs. 11:2510?2573. Doi:10..3390/md1 1072510

Mayer, A. M. S., Rodriguez, A. D., Berlinck, R. G. S., and Fusetani, N. 2011. Marine pharmacology in 2007?8: marine compounds with antibacterial, anticoagulant, antifungal, anti?inflammatory, antimalarial, antiprotozoal, antituberculosis, and antiviral activities; affecting the immune and nervous system, and other miscellaneous mechanisms of action. Comparative Biochemistry and Physiology, Part C. 153: 191 ?222

Nursid, M., Wikanta, T., Januar, H. I., dan Fajarningsih, N. D. 2006. Hubungan antara keberadaan duri dengan toksisitas karang lunak dan sponge. J urnal Penelitian Perikanan Indonesia.vol II No. Pp 83 ? 92.

Nursid, M., Chasanah, E., Murwantoko, and Wahyuono, S. 2011. Isolasi senyawa sitotoksik dari kapang Emericella nidulans. J urnal Pasca Panen dan Bioteknologi Kelautan dan Perikanan. 6 (2): 119?130

Pabel, C. T., Joachim, V., Wilde, C., Franke, P., Hofemeister, J., Adler, B., Bringmann, G., Hacker, J., and Hentschel, V. 2003. Antimicrobial activities and matrix assisted laser desorption/ ionization mass spectrometry of Baccilus isolated from the marine spons Aplysina aerophoba. Marine Biotechnology. p. $424 ? 434$.

Pawlik, J. R. 1993. Marine invertebrate chemical defenses. Chem. Rev. 93 : 1911 ?1922.

Perdicaris, S., Vlachogianni, T., and Valavanidis, A. 2013. Bioactive natural substances from marine sponges: 
new developments and prospects for future pharmaceuticals. Nat. P rod. Chem. Res. 1: 115. Doi: 10.4172/2329?6836.1000115

Plaza, A., Bifulco, G., Keffer, J. L., Lloyd, J. R., Baker, H. L., and Bewley, C. A. 2009. Celebesides A?C and theopapuamides $B$ ?D, depsipeptides from an Indonesian sponge that inhibit HIV?1 entry. J. Org. Chem. 74: 504?512.

Sadar, M. D., Williams, D. E., Mawji, N. R., Patrick, B. O., Wikanta, T., Chasanah, E., Irianto, H. E., Van Soest, R., and Andersen, R. J. 2008. Sintokamides A to E, chlorinated peptides from the sponge Dysidea $\mathrm{sp}$. that inhibit transactivation of the N?terminus of the androgen receptor in prostate cancer cells. Org. Lett. 10 (21): 4947?4950. Doi: 10.1021/ol802021w

Schmitz, F. J., Bowden, B. F., and Toth, S. I. 2001. Antitumor and cytotoxic compounds from marine organisms. Marine Biotechnology volume 1 : Pharmaceutical and Bioactive Natural Products. Edited by : Attaway, D. H. and Zaborsky, O. R. Plenum Press. New York and London. p 198.

Sennett, S. H., Mc Carthy, P. J., Wright, A. E., and Pomponi, S. A. 2002. Natural products from marine invertebrates: The Harbor Branch Oceanographic Institution experience. Pharmaceutical News. 9: 438? 488

Shen, Y. C., Lin, T. T., Sheu, J. H., and Duh, C. Y. 1999. Structures and cytotoxicity relationships of isoaaptamine and aaptamine. J. Nat. P rod. 62: 1264? 7

Trianto, A., Ambariyanto, and Muwarni, R. 2004. Skrining bahan anti kanker pada berbagai jenis sponge dan gorgonian terhadap L1210 cell line. Ilmu Kelautan. 9 (3): $120 ? 124$.

Utkina, N.K., Makachenko, A.E., Shchelokova, O.V. and Virovaya, M.V. 2004. Antioxidant activity of phenolic metabolites from marine spons. Chemistry of Natural Compounds. 40 (4): 373?377.

Wikanta, T., Januar, H. I., dan Nursid, M. 2005. Uji aktivitas antiokasidan, dan sitotoksisitas ekstrak alga merah R hodymenia palmata. J urnal Penelitian Perikanan Indonesia. II (4).

Williams, D. E. and Andersen, R. J. 2006. Coral reefs to clinical trials : bio prospecting for drugs from the sea. Proceeding International Seminar and Workshop on Marine Biodiversity and Their Potential for Developing Bio?pharmaceutical Industry in Indonesia. Jakarta.

Yong, L., Xifeng, L., Lee, U., Kang, J. S., Choi, H. D., and Son, B. W. 2006. A New Radical Scavenging Anthracene Glycoside, Asperflavin Ribofuranoside, and Polyketides from a Marine Isolate of the Fungus Microsporum. Chem. Pharm. Bull. 54(6) : 882?883

Zachary, I. 2003. Determination of cell number. In : Hughes, D and Mehmet, $\mathrm{H}$ (eds). Cell proliferation and apoptosis. BIOS Scientific Publisher Limited. 